\title{
TECHNOLOGICAL PEDAGOGICAL AND CONTENT KNOWLEDGE (TPACK) PERCEPTION OF ENGLISH EDUCATION STUDENTS
}

\author{
Mitha Septiyanti \\ English Education Study Program, Sriwijaya University, Indonesia \\ Email: mithaseptiyanti.yoko@gmail.com \\ Rita Inderawati (Corresponding Author) \\ English Education Study Program, Sriwijaya University, Indonesia \\ Email: rita_inderawati@fkip.unsri.ac.id \\ Machdalena Vianty \\ English Education Study Program, Sriwijaya University, Indonesia \\ Email: vianty.unsri@gmail.com
}

\begin{abstract}
APA Citation: Septiyanti, M., Inderawati, R., \& Vianty, M. (2020). Technological pegadogical and content knowledge (TPACK) perception of English education students. English Review: Journal of English Education, 8(2), 165-174. doi: 10.25134/erjee.v8i2.2114.
\end{abstract}

Received: 25-01-2020

Accepted: 21-03-2020

Published: 01-06-2020

\begin{abstract}
Technological Pedagogical and Content Knowledge, abbreviated as TPCK or TPACK, is the interdependent, situated knowledge needed to integrate the use of digital tools and resources effectively in curriculum-based teaching. This study aims to find out the TPACK perception of English Education students at Lampung University, the way the students obtain TPACK in learning, and the role of lecturers in assisting the students to obtain TPACK in learning. By applying a mixed method, questionnaire and interview were used to gather the data. 225 English Education undergraduate students in academic year 2018/2019 and 3 lecturers participated in this study. As result, the TPACK perception of the students was generally good as the score of all domains measured (Technological Knowledge/TK, Technological Content Knowledge/TCK, Technological Pedagogical Knowledge/TPK, Technological Pedagogical Content Knowledge/TPCK, and Technology-related Learning Experiences/TLE) was 722.1. Moreover, the students obtained TPACK by observing lecturers teaching in the classroom and doing self-learning with internet as media. Further, it was found that there were five roles of the lecturers in assisting the students to obtain TPACK in learning, namely provider, model, controller, facilitator, and motivator.
\end{abstract}

Keywords: TPACK; English dducation students; role of lecturers; students' learning; ICT.

\section{INTRODUCTION}

The role of Lembaga Pendidikan Tenaga Kependidikan (LPTK) or Teachers' Education Institution is vital as it is the institution holding the responsibility to form and prepare professional teachers. Article 1 Paragraph 14 of Law No. 14/2005 states LPTK is a university assigned by the Indonesian government to organize teacher procurement programs on early childhood education of formal education, basic education and/or secondary education, and to organize and develop education and noneducation. There are various forms of LPTK in Indonesia, including Fakultas Keguruan dan Ilmu Pendidikan (FKIP) or Faculty of Teacher Training and Education within state universities, private universities, Universitas Terbuka (UT) or Open University, Institut Keguruan dan Ilmu Pendidikan (IKIP) or former state of Teacher Training and Education Institute, private IKIP, and Sekolah Tinggi Keguruan dan Ilmu Pendidikan (STKIP) or Teacher Training and Education Academy (Ganefri, 2017).

LPTK plays an important role to provide English Education students, pre-service teachers, with knowledge and skills to teach English. According to Hudson and Nguyen (2008), EFL pre-service teachers are those who learn to teach English as a Foreign Language (henceforth, EFL). The pre-service teachers refer to EFL student teachers who have no previous experience in teaching English. In addition, pre-service is a stimulating experience that requires the application of theory to practice, or praxis, as preservice teachers transform and construct identities within often unfamiliar, fast-paced, and intense practicum environments. However, pre-service teachers (PSTs) and also inexperienced in-service teachers (ISTs), who are in the first year of their teaching profession, use information technologies 
in their classrooms in a very narrow manner and have limited knowledge about technology integration and utilization (Dawson, 2008; Ertmer, 2005; Ottenbreit-Leftwich, Glazewski, Newby, \& Ertmer, 2010; Vanderlinde, van Braak, \& Tondeur, 2010). Therefore, it is now very important for English Education students as preservice teachers to possess technology knowledge as one of $21^{\text {st }}$ century skills.

Twenty first century skills refer to 12 abilities that today's students need to succeed in their careers during the information age. One of those abilities is technology literacy. This is one of the important considerations for teachers to bring technology into the classroom nowadays. Some previous researchers have investigated how technology had important roles in learning English to enhance students' literacy (Inderawati, 2011; Fajri, Inderawati, \& Mirizon, 2015; Inderawati, Petrus, \& Jaya, 2019). Then, a specific term about integrating technology in education came up. Technological Pedagogical Content Knowledge, abbreviated as TPCK or TPACK (Thompson \& Mishra, 2007-2008), is the interdependent, situated knowledge that is needed to integrate the use of digital tools and resources effectively in curriculum-based teaching. TPACK framework provides a theoretical model for studying the ways in which teachers use Information and Communication Technology (ICT) in education.

ICT in education refers to computer based communication that is inserted into daily classroom instructional process. The ICT has strength to give a contribution to the refinement of Indonesian students' English proficiency. However, the strength of ICT will be more realized if the utilization of ICT in the classroom is also guided by principles of good curriculum design and qualified pedagogy to teach English. Voogt, Fisser, Roblin, Tondeur and Braakt (2013) believe that teachers must be familiar with various pedagogical approaches and appropriate ways to use ICT to support the development of their students' 21 st century skills. This is also strengthened by Inderawati (2017) that modern classroom must apply technology as the essential key component in the $21^{\text {st }}$ century learning. It is because expanding learning opportunities through technology is a necessary skill for English teachers today. English teachers who do not have the skills to integrate technology in their teaching practices will be out of date (Bugueño, 2013). Thus, these previous studies proved that 21 st century skills especially technology literacy must be invested by the lecturers in teacher education and TPACK can be a term to achieve that goal.

Previous studies on TPACK resulted in different findings. For example, Yan and Yuhong (2012), who examined how the pre-service English teachers could benefit from the inclusion of ICTs both as English language learners (ELLs) and would-be teachers in China, found that no matter how much the teacher knew about ICT, it could not be automatically utilized in teaching. Yan and Yuhong (2012) also reported that the integration of ICTs on pre-service English teacher education impacted on changing focus from the teaching knowledge to teaching competence, from teacher-centered to student-centered learning facilitating learners to construct knowledge. Another study conducted by Öz (2015), who carried out a research aimed to assess pre-service EFL teachers' TPACK by involving 76 preservice EFL teachers at the end of four-year teacher education program at a major state university in Turkey, found a highly developed knowledge of TPACK. Whereas the analysis of qualitative data revealed that faculty members used more TPACK in the courses than cooperating teachers at practicum schools.

In Indonesian context, an example of research study on TPACK was conducted by Mahdum (2015) who investigated the use of TPACK among Senior High School EFL teachers in Pekanbaru by using self-assessed questionnaire. The result showed that overall TPACK of English teachers in Pekanbaru was in good category. It implies that they have been able to integrate ICT, content and appropriate approach in English teaching and learning process. Another study was done by Inderawati, Sofendi, Purnomo, Vianty, and Suhendi (2019) about pre-service EFL teachers' engagement in utilizing technology for learning supports in Palembang. It showed in the first year research that there were many things to be included: the place, class management, equipment used by students, application used, instructional material used, supporting crew, and instructors' relation in learning activities.

This present study is crucial within the recent context of education in Indonesia. The Indonesian Ministry of Education (MoNE) has stated that Indonesian teachers need to integrate ICT in the teaching and learning process (Ministry of National Education, 2007a; Ministry of National Education, 2007b; Ministry of National Education, 2009). In order to support the ICT integration, MoNE has embedded on the provision of ICT infrastructure at schools by 
providing schools with computers, internet connection and online learning content (Ministry of National Education, 2010). MoNE has also embedded in various ICT related teacher professional developments (UNESCO, 2007).

Based on the explanation and facts above, the researcher was interested in conducting a research towards English Education students as pre-service English teachers. Therefore, this study aims to find out the result of TPACK perception of English Education students' at Lampung University, the way they obtain TPACK in learning, and the roles of the lecturers in assisting them to obtain TPACK in learning.

\section{METHOD}

This study applied a mixed method. Related to the purpose of this study, the researcher took English Education undergraduate students and some lecturers in academic year 2018/2019 in Lampung University as participants. The researcher used questionnaire as quantitative data and interview as qualitative data.

First, this study used a questionnaire to collect the data. In this case, the researcher distributed a set of questionnaire to be filled up by 225 students consisted of 72 in the second semester, 72 in the fourth semester, and 81 in the sixth semester in order to get perception of their current TPACK. The questionnaire about survey of technology use, teaching, and technologyrelated learning experiences among pre-service English language teachers was adopted from ready-made one by Ciptaningrum (2017). It was developed in accordance with the contexts of English as a Foreign Language in Indonesia and pre-service English teachers. The questionnaire consisted of twenty-nine questions as the main part which were divided into five domains: (1) Technological Knowledge (TK),

Technological Content Knowledge (TCK), (3) Technological Pedagogical Knowledge (TPK), (4) Technological Pedagogical Content Knowledge (TPCK), and (5) Technology-related Learning Experiences (TLE). As long as the researcher took the data, there were 187 out of 225 students from the second till sixth semester who got involved in filling out the questionnaire. Second, there were two sets of semi-structured interview conducted in order to support the first data. The first interview was constructed to some students of English Education. It consisted of six questions which aimed to find out the way they obtained TPACK in learning. Meanwhile, the second interview was administered to get information from some lecturers. It consisted of five questions related to the roles of the lecturers in assisting English Education students to obtain TPACK in learning. It was held after distributing questionnaire. There were 25 students, who were chosen by employing random sampling technique and 3 lecturers by using snowball sampling technique, participated in the interview session.

The researcher took Likert Scale form in the questionnaire as the main data. The category for each domain (five domains) was determined by its total and mean score $(\mathrm{SD}=1, \mathrm{D}=2, \mathrm{~N}=3, \mathrm{~A}=4$, $\mathrm{SA}=5$ ). Meanwhile, the results of answering descriptive questions on the questionnaire were reported in the form of percentage as supporting data. The last, it was interpreted generally and specifically to answer the first research question. For the interview, the researcher began the analysis from the transcription of interviews. Codifications of the transcription were done to identify which data could connect to answer research questions, especially the second and third research questions. Next, the researcher displayed the data from participants (English Education students, and some lecturers) thematically in order to get a clear explanation, create meaning, and reduce overlapping and repetitive data.

\section{RESULTS AND DISCUSSION \\ The result of English education students' TPACK at Lampung University}

The questionnaire items were devided into five domains: Technological Knowledge (TK), Technological Content Knowledge (TCK), Technological Pedagogical Knowledge (TPK), Technological Pedagogical Content Knowledge (TPCK), and Technology-related Learning Experiences (TLE). There were 29 items on a 5point Likert scale (Strongly Disagree, Disagree, Neutral, Agree, and Strongly Agree) which covered information about English Education students' TPACK. The following section presents the results of the analysis of the questionnaire.

\section{Students' Technological Knowledge (TK)}

The first domain was Technological Knowledge (TK). It focused on students' knowledge of new technology or digital technology, such as internet, smart phones, computers, laptops, and software programs. There were 3 items which students had given responses to. The result showed that the total score of responses on 3 items of Technological Knowledge (TK) domain was 2163 and the mean score was 721 . 


\section{Students' Technological Content Knowledge (TCK)}

The second domain was Technological Content Knowledge (TCK). It focused on the relationship between students' knowledge on how to use technology and their knowledge on non-teaching topics they studied at university. There were 10 items which students had given responses to. The result showed that the total score of responses on 10 items of TCK domain was 7854 and the mean score was 785.4.

Students' Technological Pedagogical Knowledge (TPK)

The third domain was Technological Pedagogical Knowledge (TPK). It focused on the relationship between students' knowledge on how to use technology and their knowledge on teaching topics they studied at university. There were 6 items which students had given responses to. The result displayed that the total score of responses on 6 items of TPK domain was 4465 and the mean score was 744.17.

Students' Technological Pedagogical Content Knowledge (TPCK)

The fourth domain was Technological Pedagogical Content Knowledge (TPCK). It focused on the relationship between students' knowledge on how to use technology and their knowledge on English language topics (both teaching and non-teaching topics) they studied at university. There were 6 items which students had given responses to.The result revealed that the total score of responses on 6 items of Technological Pedagogical Content Knowledge (TPCK) domain was 4075 and the mean score was 679.17.

Students' Technology-related Learning Experiences (TLE)

The last domain was Technology-related Learning Experiences (TLE). It focused on the practice of using technology in the classroom. There were 4 items which students had given responses to. The result informed that the total score of responses on 4 items of Technologyrelated Learning Experiences (TLE) domain was 2723 and the mean score was 680.75 .

Five Domains of Technological Pedagogical and Content Knowledge (TPACK)

As previously described, there were five domains of TPACK measured by Likert scale in this study. The mean score was presented in Table 1.

Table 1. Mean score of five domains

\begin{tabular}{ccc}
\hline Domains & Mean Score & Category \\
\hline TK & 721 & Good \\
TCK & 785.4 & Good \\
TPK & 744.17 & Good \\
TPCK & 679.17 & Good \\
TLE & 680.75 & Good \\
\hline The Whole Domain & 722.1 & Good \\
\hline
\end{tabular}

The first data was obtained from the students' questionnaire to answer the first research question. According to the result of questionnaire which used Likert scale, the highest mean score (785.4) was TCK domain. Then, it was followed by TPK domain (744.17), TK domain (721), TLE domain (680.75), and TPCK domain (679.17). All domains got good category. Therefore, the mean score of the whole domain was 722.1 with good category too.

Generally, English Education students at Lampung University had good perception towards TPACK. It implied that the students believe that they are able to integrate technology both on content and pedagogical subject in English learning. Specifically, the results pointed that the students' perception on Technological Content Knowledge (TCK) was the best among other domains. According to Koehler, Mishra,
Kereluik, Shin, and Graham (2014), TCK refers to inter-relationship between technology and content. Then, Richards (1998), as cited in van Olphen (2008), stated that English language content knowledge includes an understanding of linguistics components (phonetics, phonology, morphology, semantics, syntax, socio-linguistics, and pragmatics), second language acquisition, cross-cultural awareness, and language proficiency skills (listening, speaking, reading, and writing). The assumption meant almost all English Education students in that campus were able to relate their knowledge on how to use technology and non-teaching topics (content knowledge) they studied at university.

Moreover, the reason of the students' TCK was higher than their TPK was most of the students were in the first and second years of learning (2nd and 4th semester). They were still 
studying about non-teaching topics and had not passed teaching topics at the university yet, such as curriculum and syllabus design, lesson plan and material development, English Teaching (ET) method, ET assessment, Teaching English for Specific Purposes (TESP), Teaching English to Young Learners (TEYL), micro teaching, etc. It could be assumed that they prefer using technology to learn than to teach. In addition, based on the students' interview, they claimed that they always used technology daily to search for learning materials related to the content subject, such as listening and reading practice through YouTube and goodreads with or without guidance from their lecturers. The students also confirmed that they could access technology for learning purposes because they had the facilities to support their learning either at campus or at home.

Furthermore, the lowest two mean score of all was Technology-related Learning Experiences (TLE) in the classroom which was done by the lecturers and Technological Pedagogical Content Knowledge (TPCK). Although those were the lowest percentage, it still pointed good perception from the students. TPCK was the lowest because most of the students did not know how to combine technology, content, and pedagogy subjects. In other words, they have no experience in teaching English by using technology. It was in line with Dawson (2008), Ertmer (2005), Ottenbreit-Leftwich, et al. (2010) and Vanderlinde, et al. (2010) who stated that preservice teachers (PSTs) who are in the first year of their teaching professions use information technologies in their classrooms in a very narrow manner and have limited knowledge about technology integration and utilization.

Another lowest was TLE. Based on the lecturer's interview, the Head of Study Program said that it was because not all of the lecturers in that university integrated technology in their teaching. Therefore, the students did not get full learning experiences to use technology in all subjects in the classroom. There were certainly many reasons behind it all. According to the students' interview, the reasons of a few lecturers did not use technology in teaching were age factor, lack of knowledge and skill in operating technology, the lecturers were very busy to prepare supporting technology, the lecturers thought that technology, especially internet, brought more negative effects to the students, or it was only their alternative way to deliver materials more effectively. This finding was supported by
Newhouse (1999) who discussed the common barriers associated with the adoption of technology and found that the barriers preventing teachers from integrating technology were poor computer literacy, lack of time, lack of confidence, and hardware malfunctions.

\section{The way of English education students obtain TPACK in learning}

According to the result of students' interview, there were two themes which were related to the second research question; by observing their lecturers and doing self-learning.

\section{Observing the lecturers}

There were several answers from students in several questions which showed that they obtained TPACK by observing the way their lecturers taught in the classroom. It was proved by students' statements below.

"From the beginning I enter this campus until now (sixth semester), the lecturers always use technology in almost every subject. The media used are different, such as power point, email, youtube, until edmodo." (Question 3, Student 10)

"Yes. Some lecturers applied google classroom in their subjects. They teach us how to discuss in it, know the tasks given, collect, even see our score there." (Question 4, Student 6)

Most of students agreed that their lecturers had integrated and involved them to use many kinds of technology and its application, such as using power point, WhatsApp, email, YouTube, even google classroom. It is very important for teachers to have a full knowledge of technologies in teaching language skills (Pourhosein Gilakjani, 2017; Solanki \& Shyamlee1, 2012). It was because technology had an important role in promoting activities for learners and a significant effect on teachers' teaching methods. Similarly, Inderawati, Agusta, and Sitinjak (2018) found that mobile learning as one of the modes of learning had a potential effect on students' reading achievement.

\section{Doing self-learning}

In addition to observing the lecturers in campus, other data revealed that the students obtained TPACK by doing daily self-learning. It was proved by students' statements below.

"It helps me a lot in learning, because I often use several applications like goodreads for practicing my reading skill and YouTube for my listening skill." (Question 5, Student 12) 
"Technology is really helpful for me. It is because I learn English by myself (autodidact) through game, film, and also music from the internet. Moreover, because of technology, I have some friends from some continents. I often sharpen my English skills with them via message, phonecall, or even videocall." (Question 5, Student 19)

In this case, the students admitted that they got TPACK in learning more because of their own learning by using internet. They were accustomed to browse material in google, open video in YouTube, watch English film, listen English song, play online game with English subtitle, etc. According to Lam and Lawrence (2002) and Gilakjani (2017), technology assists learners in adjusting their own learning process and they are able to have access to a lot of information that their teachers are not able to provide. In other words, the students could explore many things related to learning English by using technology freely.

\section{The roles of the lecturers in assisting students to obtain TPACK in learning}

The result of lecturers' interview showed that there were five themes which were related to the third research question. The themes were as provider, model, controller, facilitator, and motivator.

\section{Provider}

The first role was provider some facilities and infrastructures related to the technology. It was pointed by two lecturers' statements below.

"Yes. This campus provides some facilities and infrastructures related to the technology. There are LCD, projector, computer, sound system, wifi, etc. Besides that, this campus has two language laboratories; university level that we call language centre (UPT Bahasa) and department level that is usually used for listening subject." (Lecturer 2)

"Yes. Coincidentally UNILA especially FKIP is now developing blended-learning. The lecturers are suggested to prepare, present, evaluate, and even communicate with the students through blended-learning (offline and online). It is supported by the campus by providing some facilities and infrastructures, such as server (internet access) in FKIP. Although it is not available in all buildings, it can still be served adequately. Then, there are university and FKIP language laboratories with all facilities inside. The last, there is a micro teaching laboratory for all departments in FKIP." (Lecturer 3)
In this case, all lecturers declared that the campus especially FKIP had provided some facilities related to the technology, such as LCD, projector, computer, sound system, and internet server. Moreover, there were also some infrastructures related to the technology to support their teaching, such as two language laboratories (faculty and university level) with all facilities inside, and a micro teaching laboratory. Besides, the best condition of teachers for integrating ICT were the teachers had good knowledge in technology, they were confident and eager to do the technology integration, and they were fully supported by facilities and infrastructures in the institution. This was in line with the research conducted by Bingimlas (2009) who elaborated that one of the major barriers in integrating ICT into teaching and learning process was lack of access to resources. Thus, it was necessary for the institution such as university to provide adequate facilities and infrastructures related to the technology in this era.

\section{Model}

The second role was model in demonstrating TPACK to the students. It was pointed by two lecturers' statements below.

\begin{abstract}
"Yes. I always use LCD every meeting when I teach students in the classroom. It is because in my opinion, technology can be integrated in almost all English subjects. I usually share and accept students' tasks through email and WhatsApp. There is also google classroom which is officially used in this year. It is for all grades but not all lecturers apply that due to each other's activities." (Lecturer 1)
\end{abstract}

\begin{abstract}
"Yes, I do. I have integrated technology in my teaching since ten years ago. I always do it for almost all subjects which I hold. For example, in qualitative research data analysis and second language acquisition (SLA), I always use videos from YouTube about the learning theories from some experts. So, the students' insight can be broader." (Lecturer 3)
\end{abstract}

Based on the result of interview, it approved the results in previous questions. The lecturers had already integrated technology to teach their subjects, although the way and the frequency were different. Lecturers needed to show the ability in using new technology like the internet and digital video in order to give example directly to the students about the utilization of technology in education, especially in English. The ability included teachers' skills in sharing and accepting students' tasks through email and WhatsApp, 
teaching students through web-based technology, such as virtual class, and using videos from YouTube about learning theories from some experts. It was supported by the statement from Murphy, DePasquale, and McNamara (2003) that teachers should model the use of technology to support the curriculum so that learners can increase the true use of technology in learning their language skills.

\section{Controller}

The third role was controller for the utilization of technology in the classroom. It was pointed by two lecturers' statements below.

"I prefer to use technology in teaching due to some reasons; it will be more interesting for students, data can be stored by all students for a long time, and it opens chance for indirectly teaching and learning when it is needed." (Lecturer 1)

"There are 2 considerations when I use technology; the availability of facility and infrastructure in faculty (e.g. LCD is ready, projector is in good condition, or even internet server does not get down at that time) and readiness of human resources in this case students in accepting material through technology." (Lecturer 2)

In fact, every lecturer had different considerations in using technology when they were in the classroom. Based on lecturers' interview, the considerations were divided into 3 categories; the readiness of lecturers, students, and environment. The lecturers' readiness included their knowledge and skill in using technology in the classroom. The students' readiness included their mental readiness in receiving learning material through technology. Whilst, environment readiness included the availability of facilities and infrastructure, condition of server, electricity, etc. On the other hand, technology was used in teaching and learning process regarding to its advantages, such as it was up-to-date, interesting, could be long lasting data, opened indirectly teaching and learning process, etc. Moreover, Koehler and Mishra (2008) asserted that teachers should also need to decide whether the technology supports or hinders the attainment of the purpose of the lesson. It was done because the lecturers' decision would influence students' learning directly or indirectly.

\section{Facilitator}

The fourth role was students' facilitator in getting TPACK. It was pointed by two lecturers' statements below.

"Yes. I always give tasks which force them to use technology. For example, in pragmatic subject, I asked them to search a film and then analyse the utterances inside. So, the students would learn how to download a film, present it in power point, cut the segments needed, etc. The point is giving the students tasks about technology will indirectly make them think how to use technology for learning. In this case, the students who have ability to do it will help the others in his/her group because it is a group work." (Lecturer 1)

"Yes. I like to challenge my students to use technology as learning media. For example, in oral translation subject, I ask them to make a video about the translation and then they must upload it in their own YouTube channel. The last, they do not need to burn the video in $C D$, they just have to send their video-link to me." (Lecturer 2)

The lecturers recognized that they were used to invite their students to use technology actively in learning with many kinds of activities, such as giving tasks which forced them to use technology, challenging students to use technology as learning media, and enriching the learning material. The goal was to get the students and technology engaged. Moreover, the use of technology has changed the teaching method from teachercentered to learner-centered. Therefore, teachers should be facilitators and guide their learners' learning and this change is very useful for learners to increase their learning (Riasati, Allahyar, \& Tan, 2012).

\section{Motivator}

The last role was motivator in encouraging students to integrate technology in their learning. It was pointed by two lecturers' statements below.

\footnotetext{
"Yes, it is really helpful in enriching and presenting material. Moreover, it can make the students be more active inside and outside classroom." (Lecturer 1)

"Yes. It is not only lecturers who get the benefits of using technology, but also the students. Through technology, the students can learn and get material needed from many sources faster, easier, more directed, and more interesting." (Lecturer 3)
} 
The three lecturers who had been interviewed were optimistic about the good impact of technology in their students' learning. The lecturers always encouraged their students to use technology because they assumed many benefits of technology for students' learning. For example, the students could learn, get, and enrich material needed from many sources in the internet faster, easier, more directed, and more interesting, present material through technology, and also give their best performances in the classroom. It was in line with Mishra's and Koehler's (2006) point of view that technology is able to provide access to explanations, representations, analogies, and demonstrations that make the subject matter more accessible to the learner.

\section{CONCLUSION}

First, the TPACK perception of English Education students at Lampung University in academic year 2018/2019 is generally in good category. It implies that the students believe that they are able to integrate technology either on content or pedagogical subject in English learning. The mean score of all domains measured (Technological Knowledge/TK, Technological Content Knowledge/TCK, Technological Pedagogical Knowledge/TPK, Technological Pedagogical Content Knowledge/TPCK, and Technology-related Learning Experiences/TLE) is 722.1. The highest mean score is on TCK domain (785.4), while the lowest one of all is on TPCK domain (679.17).

Second, there are two ways how English Education students obtain TPACK in learning. The first is by observing lecturers when they teach in the classroom. The second is by doing self-learning with internet as media.

Third, it was found that there are five roles of the lecturers in assisting English Education students to obtain TPACK in learning. The roles are provider of facilities and infrastructures related to the ICT, model in integrating ICT in the classroom, controller whether the learning material needed ICT or not, facilitator between students and technology, and motivator to encourage students to use ICT wisely.

\section{REFERENCES}

Bingimlas, K. A. (2009). Barriers to the successful integration of ICT in teaching and learning environments: A review of the literature. Eurasia Journal of Mathematics, Science \& Technology Education, 5(3), 235-245.
Bugueño, W. M. R. (2013). Using TPACK to promote effective language teaching in an ESL/EFL classroom. (Unpublished Graduate Research Papers). University of Northern Iowa.

Ciptaningrum, D. S. (2017). The development of the survey of technology use, teaching, and technology-related learning experiences among pre-service English language teachers in Indonesia. Journal of Foreign Language Teaching \& Learning, 2(2), 11-26.

Dawson, V. (2008). Use of information and communication technology by early career science teachers in Western Australia. International Journal of Science Education, 30(2), 203-219.

Departemen Pendidikan Nasional. (2005). Undangundang nomor 14 tahun 2005, tentang guru dan dosen. Jakarta, Indonesia: Depdiknas.

Ertmer, P. A. (2005). Teacher pedagogical beliefs: The final frontier in our quest for technology integration. Educational Technology, Research and Development, 53(4), 25-39.

Fajri, H. M., Inderawati, R., \& Mirizon, S. (2015). The implementation of peer editing technique to improve students' writing achievement. The Journal of English Literacy Education: The Teaching and Learning of English as a Foreign Language, 2(2), 48-57.

Ganefri. (2017). Kebijakan LPTK dalam mempersiapkan guru profesional. Jakarta: Tim Pengembang Program PPG.

Hudson, P. B., \& Nguyen, T. M. H. (2008). What do preservice EFL teachers expect from their mentors? In Australian Association of Research in Education (AARE) conference. Retrieved from http://eprints.qut.edu.au/.

Inderawati, R. (2011). From classroom to peer comment in Facebook: Bridging learners' literacy. Paper presented in the $4^{\text {th }}$ International Conference ICT for Language Learning. Pixel, Italy.

Inderawati, R. (2017). The dynamics of EFL teaching in Indonesia: Be innovative teachers through social media. English Language Teaching and Research, 1(1), 29-37.

Inderawati, R., Agusta, O., \& Sitinjak, M. (2018). The potential effect of developed reader response strategy-based mobile reading for students' establishing character and comprehension achievement. Indonesian Journal of Informatics Education, 2(2), 117-126.

Inderawati, R., Petrus, I., \& Jaya, H. P. (2019). Exploring and identifying technology-based dynamic learning through social media in academic writing. English Community Journal, 3(1), 317-324.

Inderawati, R., Sofendi, Purnomo, M. E., Vianty, M., \& Suhendi, D. (2019). Students' engagement in utilizing technology for learning support. 
ENGLISH FRANCA: Academic Journal of English Language and Education, 3(2), 181-195.

Koehler, M. J., \& Mishra, P. (2008). Introducing TPCK. AACTE committee on innovation and technology (Ed.), The handbook of technological pedagogical content knowledge (TPCK) for educators, (pp. 3-29). Mahwah, NJ: Lawrence Erlbaum Associates.

Koehler, M. J., Mishra, P., Kereluik, K., Shin, T. S., \& Graham, C. R. (2014). The technological pedagogical content knowledge framework. In J. M. Spector et al (Eds), Handbook of research on educational communications and technology, (pp. 101-111). New York: Springer Science.

Lam, Y., \& Lawrence, G. (2002). Teacher-student role redefinition during a computer-based second language project: Are computers catalysts for empowering change? Computer Assisted Language Learning, 15(3), 295-315.

Mahdum. (2015). Technological pedagogical and content knowledge (TPACK) of English teachers in Pekanbaru, Riau, Indonesia. Mediterranean Journal of Social Sciences, 6(5), 168-176.

Ministry of National Education. (2007a). Peraturan menteri pendidikan nasional republik Indonesia nomor 16 tahun 2007 tentang standar kualifikasi akademik dan kompetensi guru [The minister of national education regulation no. 16/2007 about teacher academic qualification and competency standard]. Jakarta, Indonesia: Kementerian Pendidikan Nasional.

Ministry of National Education. (2007b). Peraturan menteri pendidikan nasional republik Indonesia nomor 41 tahun 2007 tentang standar proses untuk satuan pendidikan dasar dan menengah [The minister of national education regulation no. 41/2007 about the standardize processed for primary and secondary level of education]. Jakarta, Indonesia: Kementerian Pendidikan Nasional.

Ministry of National Education. (2009). Peraturan menteri pendidikan nasional republik Indonesia nomor 78 tahun 2009 tentang penyelenggaraan sekolah bertaraf internasional pada jenjang pendidikan dasar dan menengah [The minister of national education regulation no. 78/2009 about the implementation of international standard school at primary and secondary level of education]. Jakarta, Indonesia: Kementerian Pendidikan Nasional.

Ministry of National Education. (2010). Rencana strategis pendidikan 2010-2014 [Strategic plan in education 2010-2014]. Jakarta, Indonesia: Kementerian Pendidikan Nasional.

Mishra, P., \& Koehler, M. J. (2006). Technological pedagogical content knowledge: A framework for teacher knowledge. Teachers College Record, 108(6), 1017-1054.

Murphy, K., DePasquale, R., \& McNamara, E. (2003). Meaningful connections: Using technology in primary classrooms. Young Children, 58(6), 1218.

Newhouse, P. (1999). Examining how teachers adjust to the availability of portable computers. Australian Journal of Educational Technology, 15(2), 148-166.

Ottenbreit-Leftwich, A., Glazewski, K., Newby, T., \& Ertmer, P. (2010). Teacher value beliefs associated with using technology: Addressing professional and student needs. Computers \& Education, 55, 1321-1335.

Öz, H. (2015). Assessing pre-service English as a foreign language teachers' technological pedagogical content knowledge. International Education Studies, 8(5), 119-130.

Pourhosein Gilakjani, A. (2017). A review of the literature on the integration of technology into the learning and teaching of English language skills. International Journal of English Linguistics, 7(5), 95-106.

Riasati, M. J., Allahyar, N., \& Tan, K. E. (2012). Technology in language education: Benefits and barriers. Journal of Education and Practice, 3(5), 25-30.

Solanki, D., \& Shyamlee1, M. P. (2012). Use of technology in English language teaching and learning: An analysis. In 2012 International Conference on Language, Medias and Culture IPEDR, 33, 150-156. Singapore: IACSIT Press.

Thompson, A. D., \& Mishra, P. (2007-2008). Breaking news: TPCK becomes TPACK! Journal of Computing in Teacher Education, 24(2), 38-64.

UNESCO. (2007). Initiating and managing SchoolNets. Retrieved from http:// www2.unescobkk.org/elib/publications/111/

Van Olphen, M. (2008). TPCK an integrated framework for educating world language teachers. In AACTE (Ed.), The handbook of technological pedagogical content knowledge (TPCK) for educators. New York: Routledge.

Vanderlinde, R., van Braak, J., \& Tondeur, J. (2010). Using an online tool to support school-based ICT policy planning in primary education. Journal of Computer Assisted Learning, 26, 434-447.

Voogt, J., Fisser, P., Roblin, N. P., Tondeur, T. J., \& Braakt. (2013). Technological pedagogical content knowledge: A review of the literature. Journal of Computer Assisted Learning, 29, 109121.

Yan, C., \& Yuhong, J. (2012). Integration of ICTs into subject teaching in preservice English teacher education. Proceedings of 2012 International Conference on Information Technology Based Higher Education and Training (ITHET), (pp. 15). Istanbul, Turkey: IEEE. 
Mitha Septiyanti, Rita Inderawati, \& Machdalena Vianty

Technological pegadogical and content knowledge (TPACK) perception of English education students 